Issledovatel'skiy Zhurnal Russkogo Yazyka i Literatury, Vol. 9, Issue 2, 2021, Pp: 211-224

DOI: 10.52547 /iarll.18.211 DOR: 20.1001.1.23452498.2021.9.2.11.9

Article No.: 18.111.20212.211224

Scientific Article

\title{
Eclectics of Saadi in the Works of I. Bunin and K. Paustovsky
}

\author{
Safiulina Rano Mirsachanovna ${ }^{1 *}$ \\ Associate Professor of Russian Language and Literature, Moscow University for \\ Industry and Finance «Synergy», \\ Moscow, Russia.
}

(date of receiving: May, 2021; date of acceptance: June, 2021)

\begin{abstract}
The article deals with the problem of eclecticism in the works of I. Bunin and K. Paustovsky. As a result of the analysis of the works of Russian writers, it was concluded that the eclecticism of Bunin and Paustovsky is closely related to the ideas of the Persian poet Saadi about man as a complex creature with an original "pure nature" and "engravings" imprinted on it in the process of life - traces of the knowledge of cultures, civilizations, religions, travel. This idea attracted the attention of young writers Bunin and Paustovsky and became one of the fundamental in their work throughout their lives. An analysis of works of art, memoirs, and letters of Bunin and Paustovsky in the light of the eclectic method of their creativity allows us to conclude that the goals of using this method were different for the writers. The results of a comparative analysis of the key ideas and images of Saadi in the works of Bunin and Paustovsky as a creative interpretation of the eclectic principle of the Persian poet are presented. The significance of eclecticism in the construction of the poetic world of Bunin and Paustovsky is revealed.
\end{abstract}

Keywords: Bunin I. A., Paustovsky K. G., Saadi, Eclecticism, Humanity, Eternal Values.

1. Email: ranovi@mail.ru *Corresponding author 


\title{
Эклектика Саади в творчестве И. Бунина и К. Паустовского
}

\author{
Сафиулина Рано Мирзахановна ${ }^{1 \text { * }}$ \\ Доцент кафедры русского языка и литературы МФПУ «Синергия», \\ Москва, Россия. \\ (дата получения: май 2021 г.; дата принятия: июнь 2021 г.)
}

\begin{abstract}
Аннотация
В статье анализируется проблемы эклектики в творчестве И. Бунина и К. Паустовского. В результате анализа произведений русских писателей сделан вывод, что эклектика Бунина и Паустовского тесно связана с представлениями персидского поэта Саади о человеке, как сложном существе с изначальной «чистой природой» и отпечатанными на ней в процессе жизни «чеканами» - следами знаний культур, цивилизаций, религий, путешествий. Эта идея привлекла внимание молодых писателей Бунина и Паустовского и стала одной из основополагающей в их творчестве на протяжении всей жизни. Анализ художественных произведений, воспоминаний, писем Бунина и Паустовского в свете эклектического метода их творчества позволяет сделать вывод, что цели обращения к данному методу у писателей была различными. Представлены результаты сопоставительного анализа ключевых идей и образов Саади в произведениях Бунина и Паустовского как творческой интерпретации эклектического принципа персидского поэта. Выявляется значение эклектики в построении поэтического мира Бунина и Паустовского.
\end{abstract}

Ключевые слова: И. А. Бунин, К. Г. Паустовский, Саади, Эклектика, Человечность, Вечные Ценности.

1. Email: ranovi@mail.ru * Ответственный автор 


\section{Введение}

Мысль персидского классика, поэта - суфия Саади о необходимости обогащать свою душу и сознание жизненными впечатлениями, знаниями о других людях, народах, культурах, цивилизациях пройдет лейтмотивом по всему творчеству И. А. Бунина (1870-1953) и объединит его с другим русским писателем К. Г. Паустовским (1899-1968). Строки персидского поэта: «...тридцать лет человек должен приобретать познания, вторые тридцать лет странствовать по земле, а свои последние тридцать лет отдать творчеству» будут близки и Бунину, и Паустовскому.

Эклектика как принцип собирания, объединения разных людей, культур, была противопоставлена Буниным и Паустовским тенденции разъединения, ненависти одних людей к другим, анархии, хаосу, разрушениям «Вальпургиевой ночи» по выражению автора «Жизни Арсеньева». Писателейгуманистов объединил отказ от любых попыток навязать им модернистские ницшеановские ценности с господством сверхчеловека, «культом тела», ненавистью к простому человеку, внутреннее стремление к «былой, светлой, упорядоченной жизни, к вечным, вневременным ценностям» (Благасова 2007. 107).

Эклектика - это художественный стиль или приём, характеризующийся намеренным соединением в одном произведении или образе элементов разных стилей и явлений. Принципиальное отличие эклектизма от синкретизма состоит в соединении разных культурных ценностей в единую человеческую культуру. Поэтому творческое кредо Бунина и Паустовского строится на эклектике (Сафиулина 2019. 165).

Эклектичный принцип картины мира Бунина подтверждает иранский исследователь Д. Карими-Мотаххар: «Творчество Бунина объединяет людей разных стран, разных религий, разных политических взглядов, так как для 
писателя, прежде всего, была важна личность - Вселенная, заключенная в человеческом сердце. И этим он как бы продолжает традицию великих персидских классиков, столь ценимых им...» (Карими-Мотаххар 2019. 544).

Проблема эклектики Саади в творчестве Бунина и Паустовского, рассматриваемая в данной работе, впервые поднимается в отечественном литературоведении, хотя в широком значении проблема «Бунин и Саади Ширази» достаточно глубоко изучены учеными как России, так зарубежья. Проблема «Паустовский и Саади» требует углубленного изучения. Отдельные содержательные заметки по данной теме содержаться в статье Г. П. Трефиловой (Трефилова 1971. 295-328).

Теоретическую и методологическую основу статьи составили классические и современные работы по творчеству писателей, материалы научных конференций, посвященных 150-летию Бунина и 125-летию Паустовского. Наиболее конструктивным по отношению художественного наследия Бунина и Паустовского, вобравшие в себя богатейшие слои культур народов мира, является комплексный подход, базирующийся на включении произведений автора в контекст мировой культуры и искусства, с элементами описательного и сопоставительного методов.

\section{Основная часть}

Саади Муслихиддин (1203-1291) - персидский поэт, автор поэм «Голестан» (Цветущий сад) и «Бустан» (Плодовый сад). Поэт-гуманист ввел впервые термин «адамият» - «человечность» в широком культурологическом смысле в значении «всего, что присуще человечеству как особому роду на земле, что отличает человека от других существ». Поэзия Саади со сложным суфийским подтекстом оказала большое воздействие на европейскую литературу. Слова Саади «Люди рождаются только с чистой природой, лишь потом отцы делают их иудеями, христианами или огнепоклонникам» легла в 
основу трактата «Об общественном договоре» Ж.-Ж. Руссо («Люди рождаются свободными, но живут потом в рабстве»). Знаменитая фраза из Саади о необходимости в самых сложных жизненных ситуациях вместо пустых словословий возделывать сад стала лейтмотивом творчества Вольтера. «Это вы хорошо сказали, - отвечал Кандид, - но надо возделывать сад» (Вольтер 2019. 242).

К. Г. Паустовский цитирует слова Саади в своих воспоминаниях: «Уже тогда, мальчиком, я любил сады, деревья. Я не ломал веток и не разорял птичьих гнезд. Может быть, потому что бабушка Викентия Ивановна всегда говорила мне, что "мир чудо как хорош и человек должен жить в нем и трудиться, как в большом саду"» (Паустовский 1983. Т. 4, 82).

Именно человечность персидского поэта, мудрость, неиссякаемая вера в лучшее в человеке привлекли внимание к его произведениям и русских читателей, в том числе - и А. С. Пушкина. Один из первых исследователей и переводчиков Саади С. Назарьянц отмечал в своих трудах необычность биографии и творчества восточного поэта. Среди многих достоинств персидского поэта он отмечает эклектический подход Саади к воспитанию богатой в духовном плане, многогранной человеческой личности. Чтобы стать достойным человеком, необходимо трудиться над собой, собирать себя, впитывая из многообразия мира всё самое лучшее и прекрасное. «Чтоб остепениться, привыкнуть основательно думать, понять святое назначение жизни и сделаться полезным человечеству, надо было Саади пуститься в школу действительной жизни, сталкиваться с людьми различных стран и различного покроя, наблюдать и изучать человеческий мир на поприще непосредственного опыта». Далее исследователь пишет: «И Саади добросовестно, с ненасытной жаждою познания, воспользовался каждым благоприятным случаем к обогащению себя сокровищами опыта. Вот что говорил он о себе: «"Я странствовал по всем землям, вдоль и поперек; 
разделял свое время со всеми; всякая страна доставляла мне умственное наслаждение; из каждого гумна я вынес колосья"» (Назарьянц 1857. VII).

Бунин пришел к своему увлечению Саади благодаря ученичеству у Л. Н. Толстого. «Восток, и в частности иранский мир, для Бунина не были чужими. Он, подобно величайшему иранскому поэту Саади, обозревал мир в поисках смысла бытия. Бунина волнует судьба человечества, вечные и общечеловеческие вопросы смысла бытия и обретения познания «истинного Бога» (Яхьяпур, Карими-Мотаххар 2021. 536, 545).

Следуя мудрости персидского поэта, он называл своё поэтическое творчество «чеканом», «следом» - бесконечно малым «следом» в культурной «цепи» человечества. «След» духовных открытий самых разных народов, цивилизаций, континентов виден в сложном переплетении во всем творчестве русского писателя. Этот эклектический, мультикультурный взгляд не менялся на протяжении всей жизни писателя, только углублялся, усложнялся, расширялся, обогащался в историческом и географическом контекстах (Сафиулина 2019. 165). Жизнь и творчество персидского поэта стала своеобразной путеводной звездой его исканий, не только географических, но и духовных, философских, жизненных, художественных: «Я, как сказал Саади, стремился обозреть лицо мира и оставить в нём чекан души своей» (Бунин 1988. Т.6, 544).

Саади стал близок Бунину по настрою души духовного искателя, странника, сердцем и умом обозревающего окружающий мир людей с их страстями и пороками. Писателю дорога была касыда Саади:

Бе хич яр мадех хатеру бе хич дийар, Ке барру бахр фарах асту адами бэсйар... Чу макийан бе даре хане чанд бини джор? Чера сафар накони чон кабутаре тайяр.

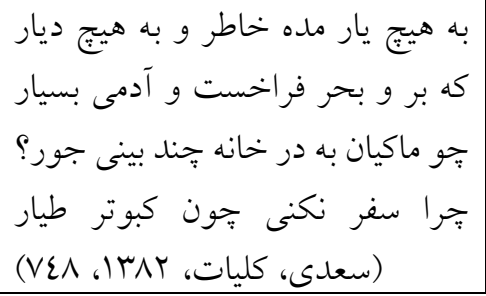


Не привязывайся сердием кместу и у душе живой.

Не сочтёшь людей на свете, не измеришь шар земной...

Что ты квохчешь в загородке глупой курицей домамней?

Почему, как вольный голубь, не умчишься в край иной?

(Саади 1974. 588, перевод И. Сельвинского)

Эти строки Саади навсегда станут заветом жизни Бунина. Он будет путешествовать всю жизнь, отправляться в новые страны и материки, открывать для себя новые миры и находить свой «след» в далеких странах. «Восток был для Бунина самоценной историко-культурной реальностью, и лирическому «я» поэта было доверено ее не столько воспринимать, сколько транслировать, пропускать через себя и фиксировать как можно объективнее» (Двинятина 2015. 101).

Мир восточных стран раскрывался перед Буниным в сложном сплетении народов, обычаев, религий. Бунин словно впитывал в себя культурные ценности восточных и христианских цивилизаций: «Далекий восточный мир изображается в произведениях Бунина как духовный, светлый. Писатель стремится погрузиться в культуру Востока, приобщиться к литературным сокровищам иранской земли и преподнести человечеству плоды собственного познания. Для выражения данных смыслов Бунин использует такие образы, как «приближение к Вечному», “аромат Сада небесного”» (Яхьяпур, КаримиМотаххар 2021. 544). Так эклектика помогла рождению бунинской философии жизни, мировоззренческой и художественной точки оценки окружающего мира, поэтому творчество писателя можно назвать культуроцентрическим, что во многом делает его предшественником О. Шпенглера, автора знаменитой книги «Закат Европы». «Максимальному субъективизму символистов Бунин противопоставляет поэзию, стремящуюся уйти от личного, биографического «Я» человека, взирающего на мир во все времена и во всех уголках земли» (Кузнецова 2019. 129). 
Творчество К. Г. Паустовского - это гармоничное переплетение мировых культурных ассоциаций, реминисценций, дискурсов, навеянных реалиями окружающей жизни и культурной памятью писателя. Она показательна и ценна своим активным включением в метаконструкцию художественного мира писателя разнообразия мира. Образы и мотивы персидского поэта Саади Ширази, его эклектического восприятия мира естественно вписались в художественные тексты Паустовского. Полюбить красоту мира во всем его эклектическом многообразии - такова жизненная и художественная программа Паустовского - писателя. Но в отличие от культурочентрического творчества Бунина произведения Паустовского антропоцентрические. На первый план у писателя выдвинут человек во всём его многообразии.

Первая встреча Паустовского с творчеством Саади произошла еще в юные годы. В своей первой критической статье «Большой человек» («Театр», Киев, 1919. ЦГАЛИ, ф. 2119, оп. 1, ед хр. 1, № 1) начинающий писатель цитирует персидского поэта: «Много лет я употребил на скитания. Я коротал дни с людьми всех народов и грелся у многих костров. Я видел частицу великой красоты, наполняющей вселенную. Тридцать лет я употребил на учение и последние тридцать лет - на творчество. Счастлив тот, кто, прожив такую жизнь, оставил потомству чекан души своей» (Паустовский 1919. 1).

Много цитат из Саади и его биографии содержат письма Паустовского его возлюбленной. Одно из первых реплик Саади звучит в письме к Загорской Е. С. от 1 апреля 1916 года: «Я вспоминаю строки Саади, шейха Ширазского, - «Будь щедрым, как пальма. А если не можешь, то будь стволом кипариса - прямым и простым, благородным», - и эти слова вызывают во мне много дум и неуловимого, радостного волнения» (Паустовский 1986. Т. 9, 37).

Основательные знания по творчеству восточных поэтов Саади, Омара Хайяма и Гафиза молодой журналист Паустовский, будучи репортером газеты «Власть народа», получил от старших собратьев по перу в Москве Шелкунова, Розовского. Для него началась пора увлечения восточной поэзией, что, 
казалось, было странно для революционной эпохи. Но Паустовский так объяснил своё увлечение: «Ощущение суровой свежести, свойственное первым революционным годам, было настолько сильным и волнующим, что накладывало отпечаток на все человеческие мысли. Идея о том, что человек нашего времени, детище революции, должен обладать не только высокими качествами, которыми в прежнее время были наделены только отдельные выдающиеся люди, но и духовными богатствами всех предыдущих эпох и всех стран, казалась мне бесспорной. И я во всем искал этого внутреннего обогащения, в том числе и в восточной поэзии» (Паустовский 1886. Т. 4, 552).

Книги великих писателей покорили молодого Паустовского, родили в нем страсть к преумножению знаний, оставленным предыдущими поколениями: «Книга, созданная руками человека, проносила мысль через времена в первозданной ее чистоте и многообразии оттенков, как бы только что рожденную. Только человеческая мысль резко сверкает в нем подобно голубой звезде Веге, как бы вобравшей в себя вест свет мирового пространства. Никакие «черные угольные мешки» вселенной не смогут затмить свет этой чистейшей звезды» (Там же. 551).

Любовь к великому гуманистическому наследию культуры человечества зародили в сердце Паустовского понимание уникальности каждого человека. Писателю были интересны все люди, встреченные на жизненном пути, неповторимое и уникальное в нем. Так, alter ego Паустовского в рассказе «Потерянный день» (1937 г.) - маленькая старенькая пассажирка автобуса, закутанная в шаль, - говорит: «А если мне интересно?!

Представьте себе, мне интересно знать про каждого человека, зачем он живет на свете». Прием эклектики писатель использует и в создании образа этой ничем, казалось, не примечательной героини. Старушка объясняет цель поездки к своим детям, живущим в разных уголках родины: «Теперь мне осталось перед смертью нелегкая должность - всех объезжать и смотреть, чтоб они не ссорились. Но где они живут! В Москве, в Горьком, в Карасубазаре, в 
Одессе, в Джанкое и Мелитополе! С такими детьми можно выучить географию» (Там же. 195).

Паустовский на протяжении всего своего творчества сохранил удивительно гармоничное восприятие мира и человека. Антропологическая константа человека Паустовского - доброта и человечность, любовь и красота, гармония и духовная чистота, всё, что спасает мир в самые тяжелые времена и эпохи. «Книги Паустовского полны редкостного доброжелательства к людям, умения даже в самом ничтожном человеке разглядеть то, что всё таки дает ему маленькое право сохранить человеческое имя. Каждая новая книга писателя ... снова и снова утверждают: нет незначительных жизней, нет неинтересных людей, не бывает ничем не поучительных встреч» (Трефилова 1971. Т. 4, 308).

Своеобразна и эклектическая философия мира Паустовского - «Его мир храм невраждебной природы, искусства и красоты - где мирно и дружелюбно соседствуют века, народы, культуры. И это обжитая земля, где каждая травинка растет для умножения прекрасного, а человек - созидатель, демиург, «венец творения». Его творчество построено на принципе личных отношений с миром. Особое зрение - поток впечатлений от увиденных картин жизни рождает особый стиль Паустовского - бессюжетную лирическую прозу» (Там же. 309).

Для создания широкой панорамы жизни Паустовский создал эклектический жанр, органически собирая в одном произведении повесть, очерк, эссе, живописную картину, научное описание, краеведческий материал.

Очерк Паустовского К. «Муза дальних странствий» строится на цитатах из Саади. Он цитирует биографию Саади из «Тезкирата», размышляет над строками его творений и соглашается с персидским поэтом, что путешествия накладывают неизгладимый след на сознании путешествующих. В странствиях по сухопутным и морским просторам земли выковываются сильные характеры, рождаются гуманность, понимание разных народов, широкие и благородные взгляды. Каждое путешествие - это проникновения в область значительного и прекрасного. 
В письме к молодым писателям от 27 декабря 1953 г. Паустовский, процитировав строки Саади, советует сохранять в себе такие духовные качества, о которых написал персидский поэт: щедрость, простоту, смелость, благородство. Писатель призывает собирать в себе большой жизненный материал, непрерывно совершенствоваться, научиться преодолевать трудности и в жизни, и в творчестве.

\section{Заключение}

Таким образом, эклектический метод Саади плодотворно сказался на творчестве Бунина и Паустовского. Разница состоит в том, что Бунин воспринимал мироздание, культурные ландшафты, народы, людей как зритель, обозревающий со стороны «чеканы» человеческой культуры - застывшие культурные артефакты. К. Г. Паустовский использовал эклектический метод для создания широчайшего антропоцентрического художественного полотна жизнедеятельности человека, включая себя как неотделимую часть мироздания и человечества в число действующих лиц мира, сотворения индивида как личности, творческого трансформирования жанровой структуры литературы.

\section{Литература}

1- Благасова Г. М., Курбатова Ю. В. (2007). И. Бунин и К. Паустовский: аксиологические параллели // Знание. Понимание. Умение. № 2. С. 107-112.

2- Бунин И. А. (1988). Собрание сочинений в 6 m. - М.: Художественная литература,

3- Вольтер (2019). Малое собрание сочинений. Пер. с фр. Г. Блока, Н. Дмитриева, Н. Коган. - СПб.: Азбука, Азбука-Аттикус, -608 с.

4- Кузнецова Е. В. (2019). Сборник И. А. Бунина «Избранные стихи» 1929 года // Творчество И. А. Бунина в историко-литературном контексте (биография, источниковедение, текстология) / Ред. О. А. Коростелев, С. Н. Морозов. - М.: Литфакт, -896 с. (Академический Бунин; вып. 1). С. 119-142.

5- Двинятина Т. М. (2015). Поэзия И. А. Бунина: Эволюиия. Поэтика. Текстология: дис... доктора филологических наук. Специальность 10.01.01. Русская литература - Санкт-Петербург, - 441 с. 
6- Ирано-таджсиккая поэзия (1974). - М.: Художественная литература, 588 с.

7- арими-Мотаххар Дж. (2019). Место и значение творчества Ивана Бунина в Иране // Творчество И. А. Бунина в историко-литературном контексте (биография, источниковедение, текстология) / Ред. О. А. Коростелев, С. Н. Морозов. - М.: Литфакт, - 896 с. (Академический Бунин; вып. 1). - С. 540-547.

8- Паустовский К. Г. (1919). Большой человек // «Театр», Киев: - ЦГАЛИ, ф. 2119 , оп. 1, ед хр. 1, № 1 .

9- Паустовский К. Г. (1983). Повесть о жизни. Начало неведомого века // Собрание соч. в 9 томах. Сост., подг. текста и примеч. Л. Левицкого. - М.: Художественная литература, Т. 4.735 с.

10- Розовый кустарник шейха Муслехеддина Саади Ширазского славный под названием Гулистана (1857). Перевод с персидского С. Назарьянца. - М.: Типография Лазаревского Института восточных языков,.

11- Сафиулина Р. М. (2019). Раннее творчество И.А. Бунина и Коран Альбера де Биберштейн-Казимирского // Творчество И. А. Бунина в историколитературном контексте (биография, источниковедение, текстология) / Ред. О. А. Коростелев, С. Н. Морозов. - М.: Литфакт, - 896 с. (Академический Бунин; вып. 1). С. 163-171.

12- Трефилова Г. П. (1971). К. Г. Паустовский // История русской советской литературы в 4-х томах. - М.: Наука, T. IV. С. 295-328.

13- Философия в “Энциклопедии” Дидро и Даламбера / отв. ред. и вступит. ст. В. М. Богуславский. - М.: Наука, 1994. С. 618.

14- Saadi M. (2003/1382). Koliaat -e Sadi//Gasaed. Tehran: Zavvar, 1147 Pp. [In Persian].

15- Yahyapour, M., \& Karimi-Motahhar, J. (2021). Иван Бунин и восточная мистика. Quaestio Rossica, 9(2), 533-546. https://doi.org/10.15826/qr.2021.2.594

\section{Bibliography}

1- Blagasova G.M., Kurbatova Ju. V. (2007). I. Bunin $i$ K. Paustovskij: aksiologicheskie paralleli // Znanie. Ponimanie. Umenie. № 2. S. 107-112.

2- Bunin I.A. (1988). Sobranie sochinenij v 6 t. - M.: Hudozhestvennaja literatura,

3- Vol'ter (2019). Maloe sobranie sochinenij. Per. s fr. G. Bloka, N. Dmitrieva, N. Kogan. - SPb.: Azbuka, Azbuka-Attikus, - 608 s.

4- Kuznecova E.V. (2019). Sbornik I. A. Bunina "Izbrannye stihi» 1929 goda // Tvorchestvo I.A. Bunina $v$ istoriko-literaturnom kontekste (biografija, istochnikovedenie, tekstologija) / Red. O.A. Korostelev, S.N. Morozov. - M.: Litfakt, - 896 s. (Akademicheskij Bunin; vyp. 1). S. 119-142. 
5- Dvinjatina T.M. (2015). Pojezija I.A. Bunina: Jevoljucija. Pojetika. Tekstologija: dis... doktora filologicheskih nauk. Special'nost' 10.01.01. - Russkaja literatura Sankt-Peterburg, - 441 s.

6- Irano-tadzhikskaja pojezija (1974). - M.: Hudozhestvennaja literatura, 588 s.

7- Karimi-Motahhar Dzh. (2019). Mesto i znachenie tvorchestva Ivana Bunina v Irane // Tvorchestvo I.A. Bunina $\mathrm{v}$ istoriko-literaturnom kontekste (biografija, istochnikovedenie, tekstologija) / Red. O.A. Korostelev, S.N. Morozov. - M.: Litfakt, - 896 s. (Akademicheskij Bunin; vyp. 1). - S. 540-547.

8- Paustovskij K.G. (1919). Bol'shoj chelovek // «Teatr», Kiev: - CGALI, f. 2119, op. 1, ed hr. 1, № 1 .

9- Paustovskij K.G. (1983). Povest' o zhizni. Nachalo nevedomogo veka // Sobranie soch. v 9 tomah. Sost., podg. teksta i primech. L. Levickogo. - M.: Hudozhestvennaja literatura, T. 4. $735 \mathrm{~s}$.

10- Rozovyj kustarnik shejha Musleheddina Saadi Shirazskogo slavnyj pod nazvaniem Gulistana (1857). Perevod s persidskogo S. Nazar'janca. - M.: Tipografija Lazarevskogo Instituta vostochnyh jazykov,

11- Safiulina R.M. (2019). Rannee tvorchestvo I.A. Bunina $i$ Koran Al'bera de Bibershtejn-Kazimirskogo // Tvorchestvo I.A. Bunina v istoriko-literaturnom kontekste (biografija, istochnikovedenie, tekstologija) / Red. O. A. Korostelev, S. N. Morozov. - M.: Litfakt, - 896 s. (Akademicheskij Bunin; vyp. 1). S. 163-171.

12- Trefilova G.P. (1971). K.G. Paustovskij // Istorija russkoj sovetskoj literatury v 4-h tomah. - M.: Nauka, T. IV. S. 295-328.

13- Filosofija v "Jenciklopedii" Didro i Dalambera / otv. red. i vstupit. st. V.M. Boguslavskij. - M.: Nauka, 1994. S. 618.

14- Saadi M. (2003/1382). Koliaat -e Sadi//Gasaed. Tehran: Zavvar, 1147 Pp. [In Persian].

15- Yahyapour, M., \& Karimi-Motahhar, J. (2021). Ivan Bunin and Eastern Mysticism. Quaestio Rossica, 9(2), 533-546. https://doi.org/10.15826/qr.2021.2.594

\section{HOW TO CITE THIS ARTICLE}

Safiulina R. M. (2021). Eclectics of Saadi in the Works of I. Bunin and K. Paustovsky. Issledovatel'skiy Zhurnal Russkogo Yazyka I Literatury, 9(2), 211-224.

DOI: $10.52547 /$ iarll.18.211

URL: https://www.journaliarll.ir/index.php/iarll/article/view/206 


\section{التقاط سبك ادبى سعدى در آثار اى. بونين و ك. يااوستوفسكى}

$$
\begin{aligned}
& \text { رعنا ميرزاخانوونا صافيئولينا '" } \\
& \text { دانشيار كروه زبان و ادبيات روسى دانشگاه اقتصاد و صنعت مسكو (اسينركيا)، }
\end{aligned}
$$

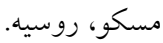

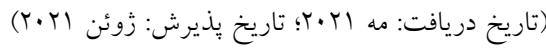

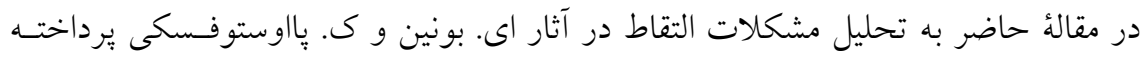

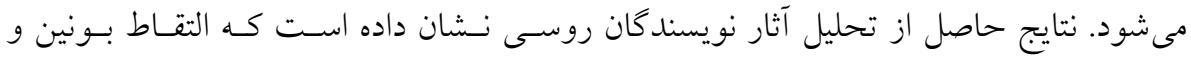

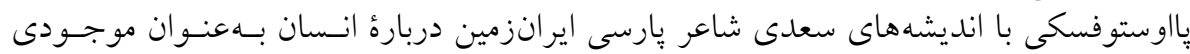

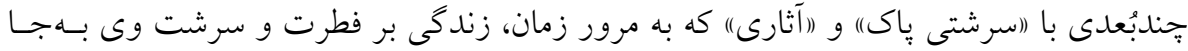

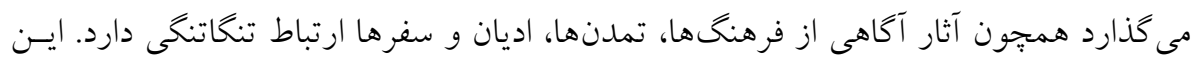

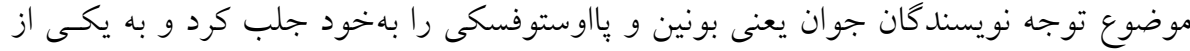

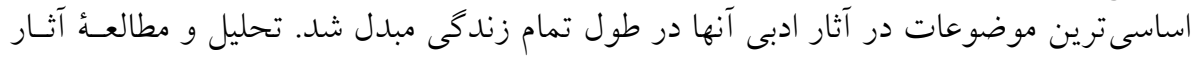

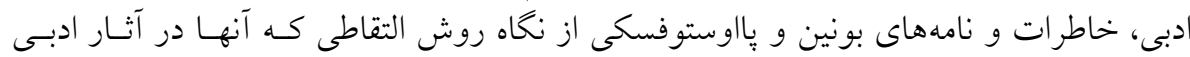

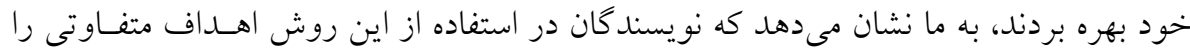

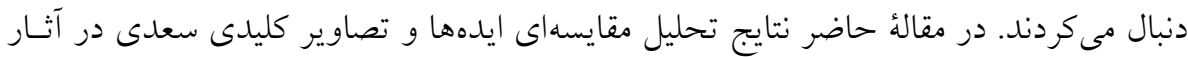

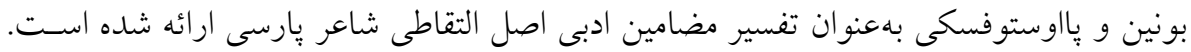

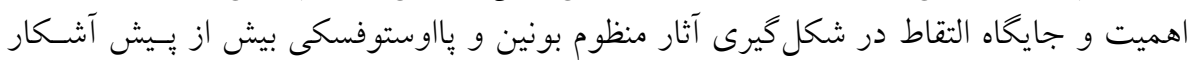
مىشود.

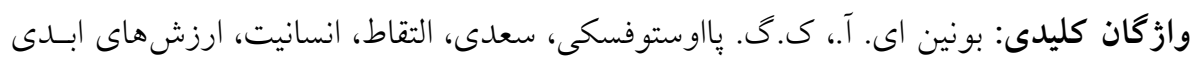
و مطلق.

1. Email: ranovi@mail.ru نويسنده مسئول * نوع مقاله: علمى - يزوهشى 